\title{
左耳前部に生じた石灰化上皮腪の症例
}

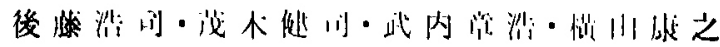

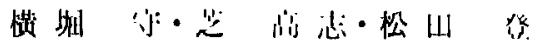

\section{A case of calcifying epithelioma in the left preauricular region}

\author{
Koji Goto - Kenji Mogil Akihiro Takeucill - Yasuyuki Yokoyama \\ Mamoru Yokoborı - 'litkashi ShiBa = Noboru MATsuda
}

\section{I. 粕}

石爽化上皮腫（calcifying epithelioma）は，1880年

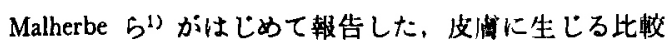
的発生頻度の少ない良性腫㻛の1つである．石灰化上皮 尰は皮局科からの報告2ー7は多いか，口腔頒域では少な い,8 19)，今回，著者らは左耳前部に発生した石灰化上皮 尰の1例を程釦し，摘出物の走查電顕による覞察および $2 ， 3$ の物理化学的性状の検索をむ行ったので赧告す 万.

\section{II. 症}

\section{例}

\section{患者：6歳 男罗. \\ 初診: 昭和55年 4 月曰日. \\ 主 訴: 左耳前部の腫瘤.}

家族厢および既往歴：特記事項はない。

現病歴：昭和54年11月中旬頃より左耳前部に無捅性, 可動性の腫瘤があるのに気づいたが，自覚症状がないた め放固した．昭和55年 2 月頃より增大傾向を示したので 気になり某歯科医院を受診したところ，当科を紹介され 来院した。

\section{現 症}

全身所見：体格，栄盖ともに良好で異常はみられな W.

局所所見：左耳前部の皮膚に青紫色の尰脹が認められ

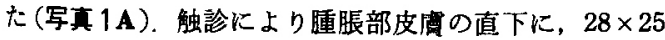
$\times 5 \mathrm{~mm}$ の境界明膫な不整四角形の骨様の硬さの尰瘤を 触れたが，压痛はなかった，畽瘤の表面は皮覤とは軽度 に窟着しているように思われたが，底部での癋着はなく 可動性で指でつまみあげられた（写真1 B ）。なお，左側

群馬大学医学部口膑外科学教室

（主任：松田 登教授）

Department of Oral Surgery, School of Medicine, Gunma Univesity (Chief: Prof. Noboru Matsuda)

受付日：昭和58年 1 月 13 日

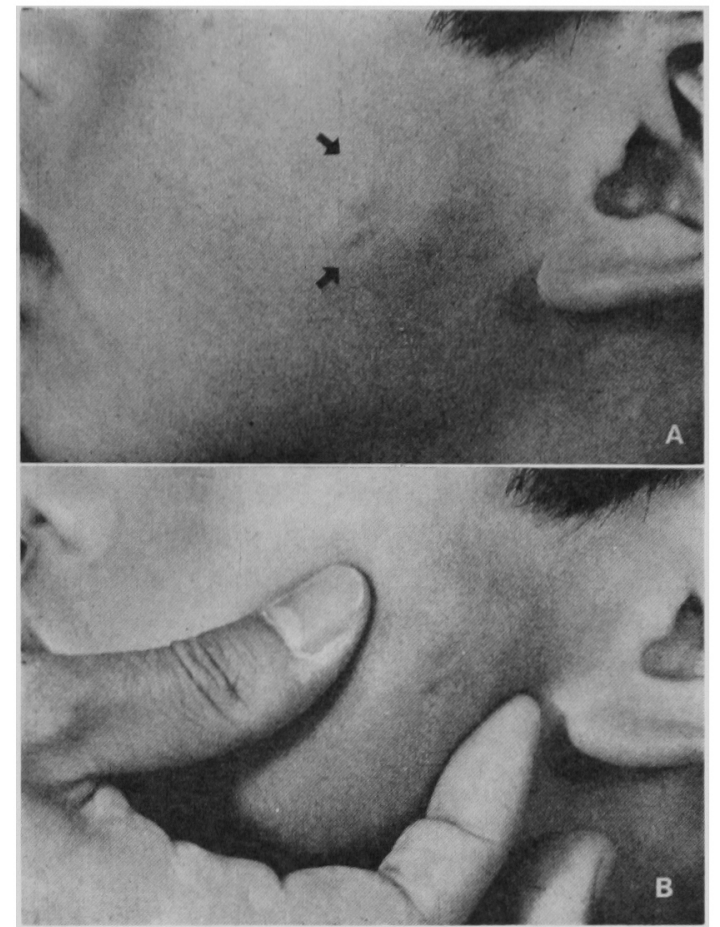

写兵 1 初時, 局所所見

A：左耳前部の青紫色の腫留を示す

B：腫瘤は可䡉性で指でつまみあげられる

の煩粘膜には巽常所見はなかった，罰下゙リン゚゚節は触れ なかった。 また食事時に耳下腺部の腫脹や疼痛を生じる ことはなかった。

$\mathbf{X}$ 線所見：単純撮影では特に異常所見は認められず, 左側耳下腺造影では斑紋状像を示し，導管系の变化およ び造影像の欠落はなかった（写真 2 A)．ぜロ ラジオダ ラフィーでは，左耳下腺直上部に雀卵大の類円形の不透 過像がみられたが，耳下腺との関連はないと思われた

(写真 2 B).

臨床挨查成績：末梢血椧查，血清生化学検查成績には 異常所見は認められなかった。 


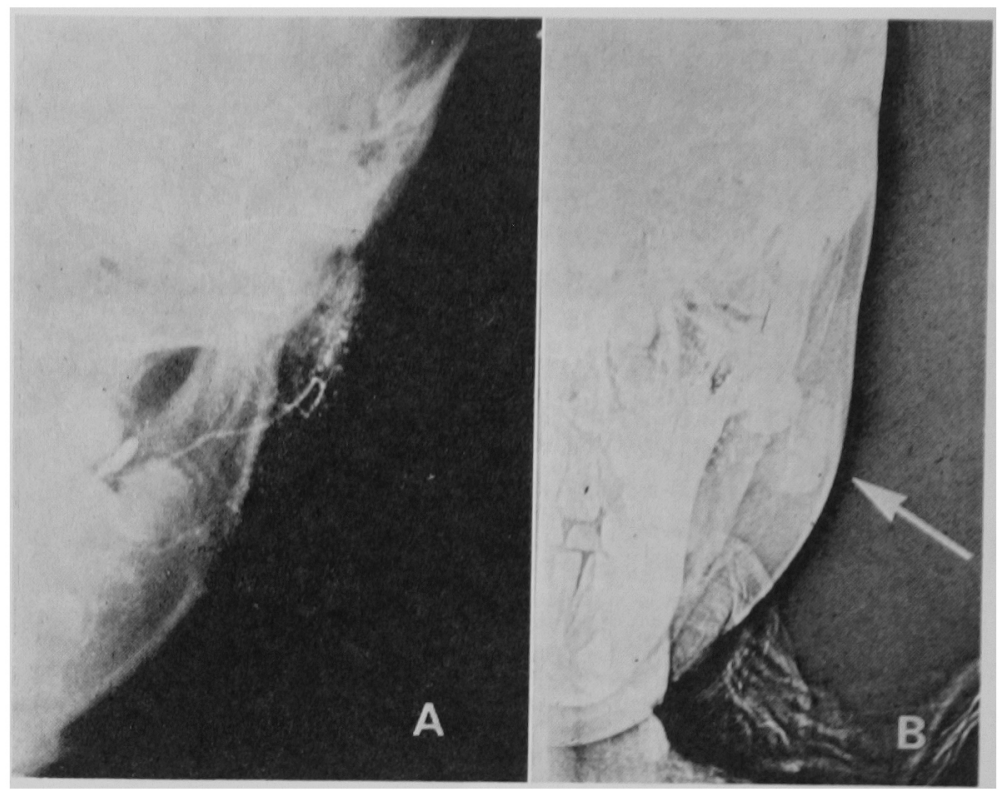

写直 2 初猃時, X線写真

A：左側耳下腺邀影像（顔正面前後方向振影）

B：ゼロラジオグラフィー（矢印は類円形の不透墖像を示す）

臨床診断：左耳前部石灰化上皮隀の疑い．

処置および経過：昭和55年 5 月日日試験切除を行った ところ, 病理組織学的にも石灰化上皮腫上㟝断されたの

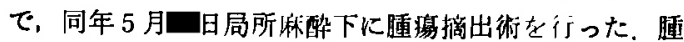
場は薄い被膜で被われ，周囲との癒着はなく谷易に摘出 できた，耳下腺との関連は認められなかった，術後のぜ ロラジオクラフィーで腫凊は完全に摘出されており（写 真 3 ), 治瘾経過も良好であった，写真 4 は術後 2 年 3 か 月の所見であるか，再発傾向は認められない

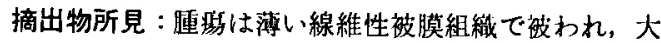
きさは約 $15 \times 10 \mathrm{~mm}$ ，色は灰白色で，一部に照色の部分

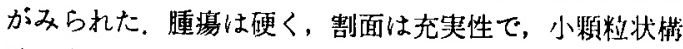
造を有する石成化物と考えられた（写直 5).

病理組織学的所見：皮下組織内倕周上皮の結節性增 殖がみられるが（写真 $6 \mathbf{A}$ ), 大部分は壤死に陷り ghost 化し，陰影細胞として認められる（写直6 B ）。むた，好 塩基細胞の陰影細胞への移行像も認められた，上皮細胞 栄の周囲には，異物型巨細胞が多数存在する(写直 $6 \mathbf{B}$ ). 間質には，小円形細胞や好中球の軽度の浸潤が認められ る（写真 $6 \mathbf{A}$ )。扁平上皮細胞巣には，軽度の石炎沈着 が認められる(写直 6 B).

走查電顕所見：通法に従い走查電湿試料を作製し，日 本電子社製 JSM-U 3 型走查電子䫒徽鏡で腫㸞断面を観 察した，写真 $7 \mathbf{A}$ の多孔質・海綿状のシワ構造物 (a) のなかに, 白い島状あるいは点状の構造物 (b) がとこ ろどころに散在している，白い島状の構造物を払大する

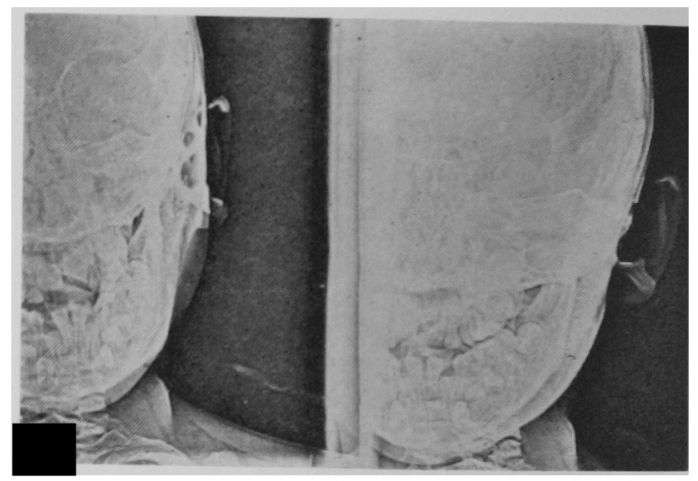

写率 3 街後，ぜロラジオクラフィー（接線方向） 踵瘦の存は諟められない

と、なかにチュープの切り口状の構造がみられた（写真 7B）。ある部位の肚大像では, 複雜に入り組んだ胗原線 稚と思われる絧状構造のなかに, 石灰化の結晶を思わせ

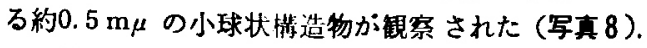

X線回折による分析：粉末 $\mathrm{X}$ 線回折計により, Ni フ イルターを用い，スリット $1^{\circ} ， 0.31^{\circ} て ゙$, 加速電生 $30 \mathrm{kV}$, $10 \mathrm{~mA}, 800 \mathrm{cps}$ て X線回折図形をとった。角度 20 か $11.0^{\circ}$ から50。 までの回折像では，ハイドロキシアハタイト系 結晶物質と思われた（写真9).

X線マイクロアナライザー所見：走查電影所見で白い 島状にみえた部分について $\mathrm{Ca}, \mathrm{P}$ の特性 $\mathrm{X}$ 線像を撮影 し，その元素分布状態を調べた，撮影条件は $30 \mathrm{kV}, 800$ 


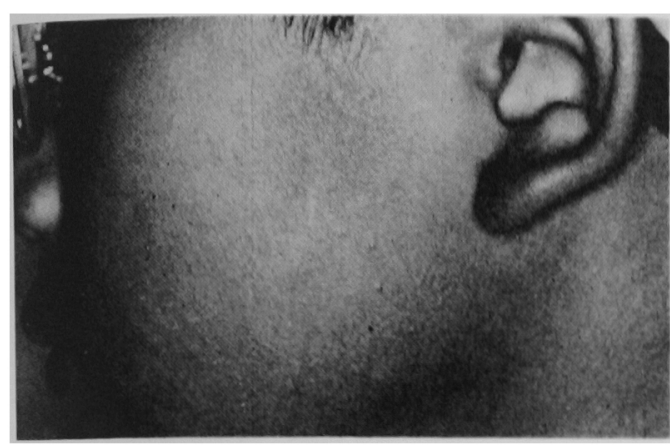

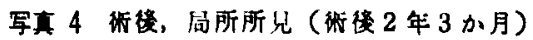

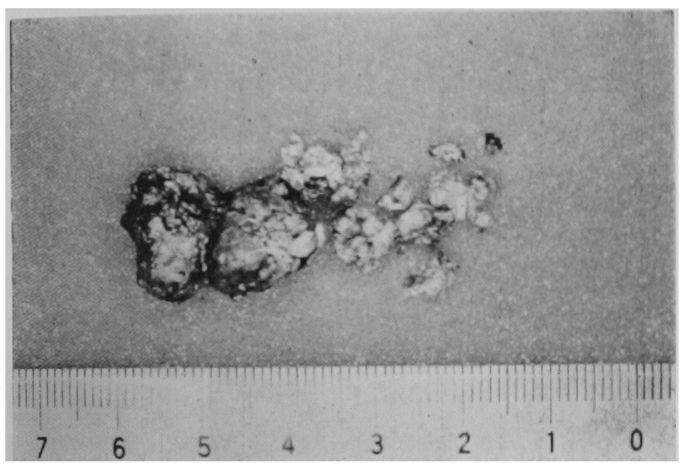

写真 5 摘出物所見

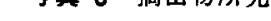

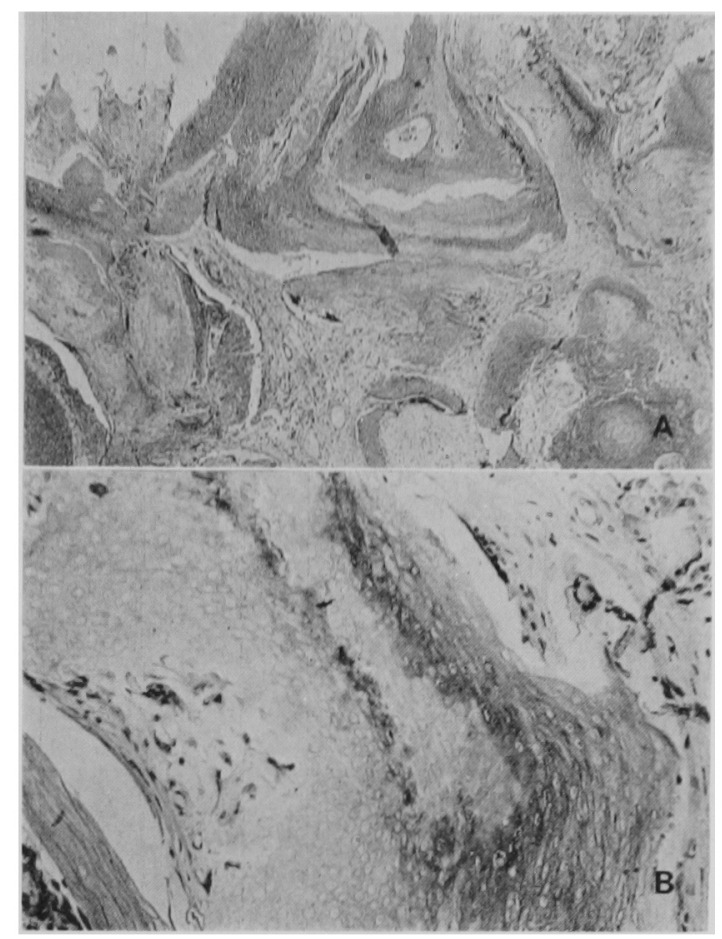

写牙 6 病理組䢂像 ( $\mathrm{H}-\mathrm{E}$ 染色)

$(A: \times 35 \quad$ B $: \times 220)$

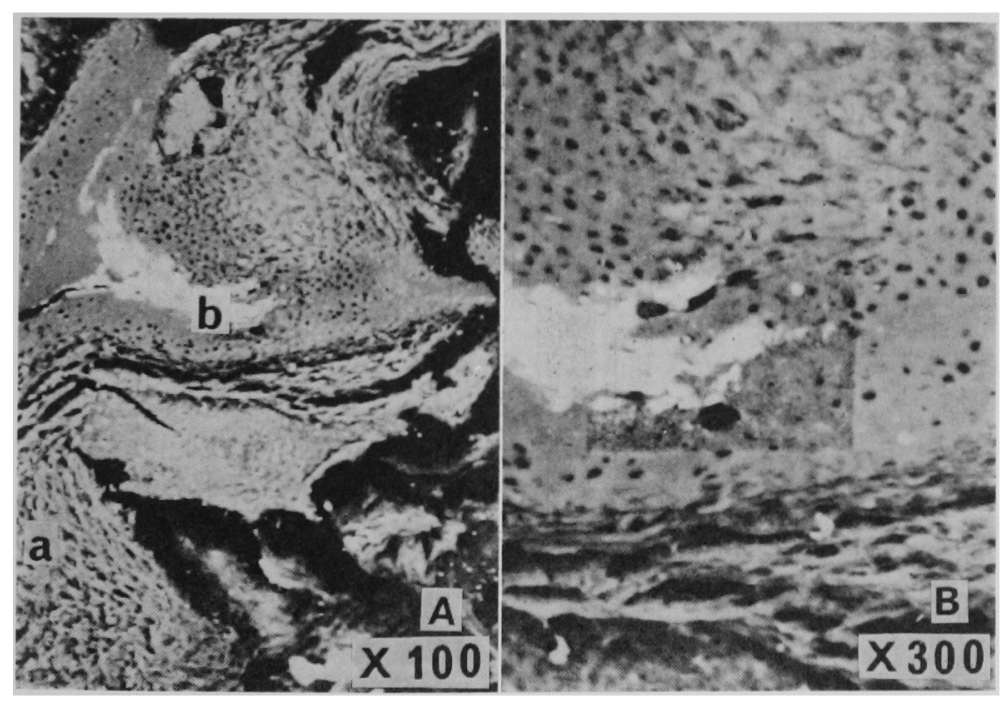

写氠 7 走查電影像 


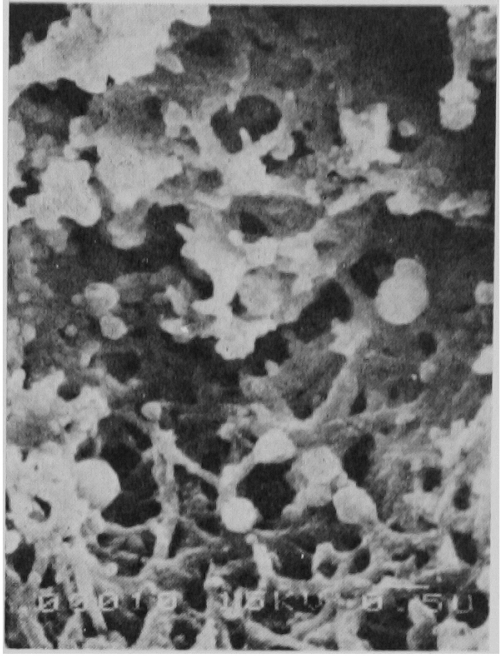

写直 8 走查他显像 $(\times 3,500)$

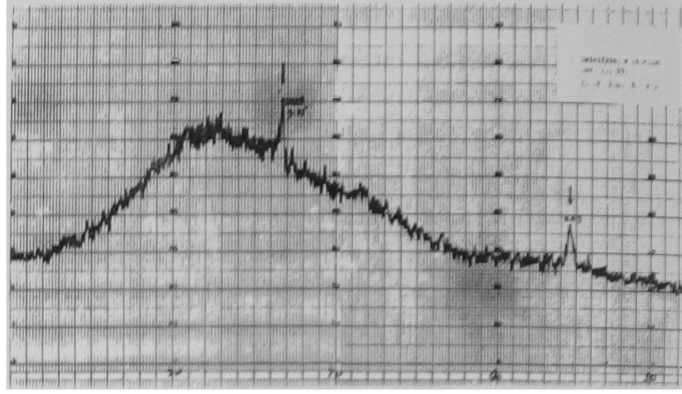

写筑 9 X緗回折像

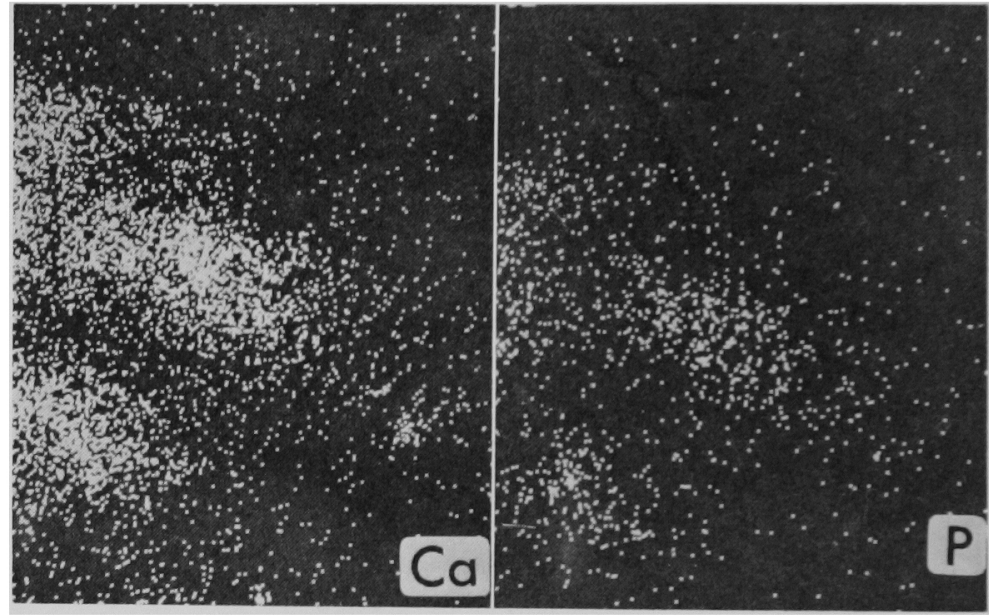

军真 10 X線マイクロアナライザー所見

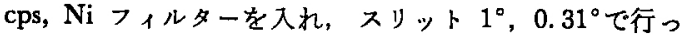
た，写真7の白い島状部分については，写高10のよ5 に， $\mathrm{Ca} ， \mathbf{P}$ が密に集中しており，石灰化の著しい棈造 物と思われた。

\section{III. 考察}

石灰化上皮腫 (calcifying epithelioma) は，比較的少 ない良性腫瘍で，発生部位の関俰から和もに皮肉科・外 科領域の疾患として取り扱われているので，口院外科領 域からの報告8〜13)は少ない。

本腫癔の発生由来および本態については，また十分解 明されていないので，種々の説がみられる、すなわら，
Malherbe $5^{1)}$ は脂腺または脂腺上皮が迷入し，異常増

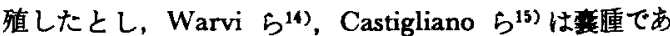
ると報告しているが， $\mathrm{Ch}^{\prime}$ in $^{18)}$ は基底細胞上皮腫と考え ている。また，Fink ${ }^{17)}$, Côte ${ }^{18}$ ， King ${ }^{19)}$ は表皮菨㣫と 基底細胞上皮腫の中間のものと想定している. 一方, Turhan $5^{20)}$ は石灰化上皮腫の腫瘍実質細胞のうち好塩 基細胞は hair matrix cell に, 陰影科胞は未熟な hair cortex cell に相当し, 本連場は毛髹形成の過程に出現 する腫湯であると考えた。ささらに Lever ら 細胞を角化性毛母細胞一分化する㑯向を有する第一次上 皮芽細胞とみなし，また好塩基紼胞から陰影細胞への移 行型がみられることより，陰影細胞はより未熟で毛母基 質細胞から由来すると考えた，そして，今日では，石灰 


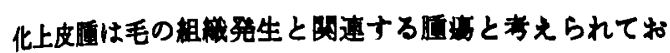

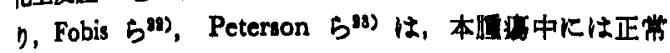

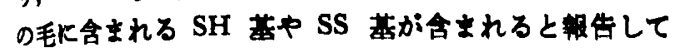
いる.

本遖高の名称については，一般的には石灰化上皮助 (calcifying epithelioma)と呼ばれているが, epithelioma が思性のむのを思わせることから Fobis ら日は pilomatrixoma, Hulett ${ }^{21)}$ は trichomatrixoma と呼ぶことを提 唱している，その他，pilomatricoma の名称る付けられ ている.

本症の発生部位であるが，一轧に面・頻部・上肢に 多く，全体の $80 \%$ は前述の部位に生じるといわれてい る. 頭顓部における好発部位は，上眼瞹部，届毛周囲部、 耳前部、耳啳部、到部の毛のはえきわ，胸銧乳突筋の後 绿に治ら部分であるので，耳前部に生じた本症例のよう に口腔外科を受診することが起こる。.

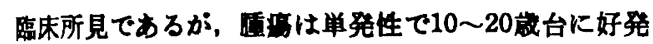
し，表面は正常な皮庙で被われ良性の経過を示与。しか し，ときには黄白色, 淡裸色, 淡青色ないし淡赤色を旺

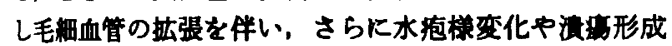
がみられることるあるといら，水疮形成は衣服などとの 摩繁によることが考えられているが．本症例では一部 が暗紫色を呈し，毛細血管の払張も認められた。

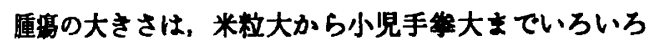
であるが，多くは小指頭大で発見される．自検例では拇 指頭大であり，比較的大きい症例と思われる，男女间で の発生頻度の差はなく，また悪性化をきたす症例はな W.

本症の診断に凰しては, 確定診断は組織学的所見によ っている. 組織像の特徽は，原則として好塩基細胞と陰 影細胞の 2 種類の細胞からなっている．そのうち好塩基 細胞怯大型で円形ないし棈円形の核を持ち，好塩基性を 示ナ. 一方, 陰影細胞は H-E 染色でわずかに好䭒性に

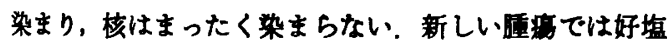
基細胞が豊富に存在するが，陳旧化するにつれて陰影細 胞が多くみられるようになる。 また，ある部分では両細 胞の移行型とみなされる移行細胞をみることがある4,22, 25,26)

本症例では，好塩基細胞・陰影細胞・移行細胞のすべ てが存在し，さらに石灰化むみられ，やゃ陳旧化した像 を示す症例と考えられる。

著者らは摘出物について走查電影像，ならびに 2,3 の物理化学的性状について検討を加えたが，この種の報 告は唾石，静脈石に比較して少ない. Hashimoto $5^{27)}$ は, 本隀瘦細胞の分化, 角化過程を電顕的に钼察し, 好 塩基細胞から陰影細胞への移行層において, 形質膜の菲 薄化ないし消失，線維内セメント物質 ( $r$ ーケラチン) と結合した電子密度の高い $\alpha$ ーケラチンの肥厚 した束が 豊副にみられ，また $\mathrm{Ca}$ の沈着線は， $\alpha$ ーケラチン線維
のまわりに顆料状あるいは線䊒状の結腯としてみられる

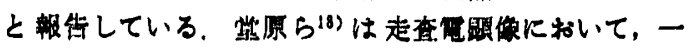

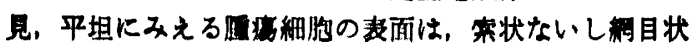
を星し，ある部位においては裉猚に入り組んだ綵維性の

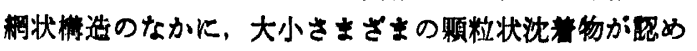
られたと述ぺている，この所見は，落者らの腰原紋䧴を 思わせる䌊状档造のなかに石灰化の結最を思わせる小球

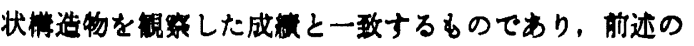

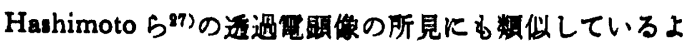
ろに思われた。

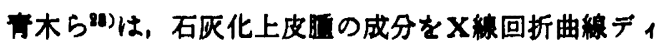
フラクトメーターを利用して㭘在し，海石执よひ臣石に みられるハイドロキシフハタイトと同一の所見を得たと 述ペており，自鉒例のX線マイクロフナライザーの結果

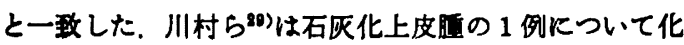
学分析を行い，燐酸塩，炭酸塩， $\mathrm{Ca}, \mathrm{Mg}$ を模出してお ク，これらの報告もまた成鿓の項で述べた石灰化物は Ca, P を主とするハイドロオキシフバタイトである所見 を支持する资料となった，走查笔影ならびに物理化学的 性状に咸する著者らの所見は，1症例について検索した むのであり，今後さらに梌討を要すると考える.

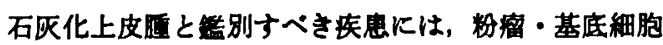
上皮遁があげられるが，本症は一度経㰸すると稪床像か ら比较的正しい診断をつけ中すく，少なくとる舞いを持 つことのできる垁患であるが，確定するためには，さら に好塩基細胞や陰影細胞の有無により組織の上から区別 される．本症例では耳前部に生じたので耳下腺唾石症と の鑑別を要した．耳下腺唾石との区別のためX線造影法 が行われるが，本症例で用いられたぜロラジオクラフ 一は両者の監別に有力な情報を提供した.

本症の処置は摘出で十分であり，再発はほとんどない といわれている，本症例でも腫瘦のみの摘出処貫で，2 年を経過するが再発は認められない.

$$
\text { IV. 結 語 }
$$

6 葴の男児の耳前部に発生した石灭化上皮原の 1 例を 経験した，本腫疱は比較的少ない腫掦であるが，顔面， 頚部に発症することが知られており，口腔外科医が念頭 に置かねばならない疾患の1つであると考えて報告し た.

本論文の要旨は, 昭和56年第26回日本口腔外科学会総 会で啹告した。

走査電影および物理化学的性状の榆討にさいしてこ指 学、こ協力をいただいた東京医科菌科大学附属医用器材 研究所加藤一男教授, 東京医科科大学第 1 保存学講座 高津寿夫䍀師に深碀する。 


\section{引用文 䰚}

1) Malherbe, A., et al.: Note sur l'épithelliome calcifié des glandes sébacées. Prog Med Pario 8: 826 1880. 22) 上り引用。

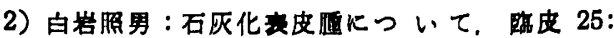
8691971.

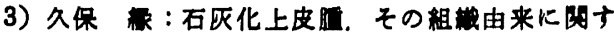
万考察。踦皮 27: 6451973.

4) 平林 伦，他: Calcifying epithelioma(Malherbe). 皮比 15: 1471973.

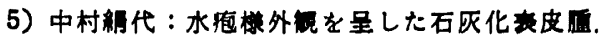
臨皮 29: 9471975.

6）永井替子，他：水窇㥞变化を伴った石灰化上皮 目. 日皮会誌 86：755 1976.

7）金丸他：表面一部水疱状を呈した巨大石

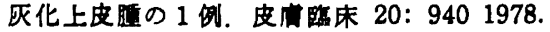

8）川田雄样, 他：煩部にみられた calcifying epithelioma の症例，口外誌 7:68 1961.

9）小宮山一雄, 他: Pilomatrixoma の礛床病理学 的检刢. 日大学 51: 8611977.

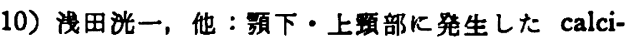
fying epithelioma の 1 例. 日外誌 23: 729 1977.

11）鈴木和彦,他：右偩下部に発生した calcifying epithelioma の 1例。 日外誌 24：619 1978.

12）石川武憲,他:いわゆる石灰化上皮腫(Malherbe) の 1 症例飞おける病理学的所見からみた文献的 考察。日口外誌 24: 13441978.

13）堂原券美，他：石灰化上皮值の 2 例，日口外誌 25: 11911979.

14) Warvi, W.N., et al.: Epithelial cysts and cystic tumor of the skin. Am J Pathol 19: 7651943.

15) Castigliano, S.G., et al.: Benign calcifying epithelioma of the skin. Arch Dermatol Syph 70: 5901954.
16) Ch'in, K.Y.: Calcified epitheliome of the skin. Am J Pathol 9: 4971938.

17) Fink, W.: Die verkalkenden Epitheliome der Haut und ihre Beziehungen zu Organisationsvörgăngen in Atheromen. Arch Pathol Anat 289: 5271933.

18) Cote, F.H.: Benign calcified epithelioma of the skin. J Pathol 43: 5761936.

19) King, L.S.: Mummified epidermal cysts (10called Calcified epitheliomas). Am J Pathol 23: 291947.

20) Turhan, B., et al.: Bemerkungen úber die sogenannten verkalkenden Epitheliome der Haut und ihre Genese. Delmatologica 85: 73 1942.

21) Lever, F.W., et al.: Calcifying epithelioma of Malherbe. Histopathology of the skin. V. ed 15. Lippincott Co, Philadelphia, 1975, p 506.

22) Fobis, R. Jr., et al.: Pilomatrixoma(calcifying epithelioma). Arch Dermatol 83: 6061961.

23) Peternon, W.C. Jr., et al.: Calcifying epithelioma of Malherbe. Arch Dermatol 90: 404 1964.

24) Hulett, R.M.: Trichomatrioma. A clinicopathologic entity separable from calcifying epithelioma of Malherbe. AMA Arch Dermatol 77: 285 1958. 22) 上り引用.

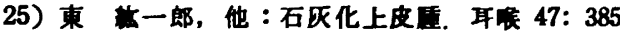
1975.

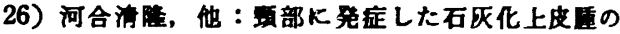
1 用. 耳展 20:837 1977.

27) Hashimoto, K., et al.: Calcifying epithelioma of Malherbe. J Invest Dermatol 46:391 1966.

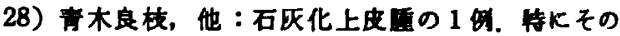
成分にっいて。東女医大结 35: 2701965.

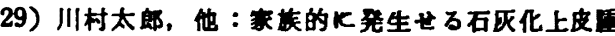
の2价に部いて。皮性誌 45：147 1939. 